Performing Piety 
THIS PAGE INTENTIONALLY LEFT BLANK 
( KARIN VAN NIEUWKERK )

\section{Performing Piety}

SINGERS AND ACTORS IN

EGYPT'S ISLAMIC REVIVAL

University of Texas Press 
Copyright $\odot 2013$ by the University of Texas Press

All rights reserved

Printed in the United States of America

First edition, 2013

Requests for permission to reproduce material from this work should be sent to:

Permissions

University of Texas Press

P.O. Box 7819

Austin, TX 78713-7819

http://utpress.utexas.edu/index.php/rp-form

(a) The paper used in this book meets the minimum requirements of ANSI/NISO Z39.48-I992 (RI997) (Permanence of Paper).

LIBRARY OF CONGRESS CATALOGING-IN-PUBLICATION DATA

Nieuwkerk, Karin van, 1960-

Performing piety : singers and actors in Egypt's Islamic revival / By Karin van Nieuwkerk.

p. $\quad \mathrm{cm}$.

Includes bibliographical references and index.

ISBN 978-0-292-74586-5 (cloth : alk. paper)

I. Entertainers-Religious life-Egypt. 2. Entertainers-EgyptBiography. 3. Islamic renewal-Egypt. I. Title.

PN2977.N535 2013

$792.70962-\mathrm{dc} 23$

2013000931

doi: $10.7560 / 745865$ 
Dedicated to my sons Ruben and Leander 
THIS PAGE INTENTIONALLY LEFT BLANK 